\title{
Congenital Nephrotic Syndrome due to Congenital Syphilis: A Case Report
}

\author{
Gislaina Melo de Oliveira Nascimento Toledano ${ }^{1}$, Carla Oliveira Cardoso ${ }^{1^{*}}$
}

${ }^{1}$ Federal University of Triangulo Mineiro, BRAZIL

*Corresponding Author: carla_cardoso@hotmail.com

Citation: Toledano GM de ON, Cardoso CO. Congenital Nephrotic Syndrome due to Congenital Syphilis: A Case Report. Electron J Gen Med. 2021;18(2):em280. https://doi.org/10.29333/ejgm/9731

\begin{tabular}{|c|c|}
\hline ARTICLE INFO & ABSTRACT \\
\hline Received: 19 Aug. 2020 & A 2 month-old baby was admitted to our emergency unit presenting hypoactivity, hyporexia, \\
\hline Accepted: 10 Dec. 2020 & $\begin{array}{l}\text { hepatosplenomegaly, hyperlipidemia, oliguria and generalized edema, compatible with congenital nephrotic } \\
\text { syndrome. Additional investigation evidenced a reactive non treponemal test and her mother was untreated for } \\
\text { gestational syphilis. No specific measure for nephrotic syndrome was taken, intravenous penicillin } \mathrm{G} \text { was } \\
\text { administered for } 10 \text { days with total remission of symptoms. Follow up after discharge confirmed that congenital } \\
\text { syphilis was the cause of congenital nephrotic syndrome. Since syphilis case reports have been increasing } \\
\text { worldwide, physicians should be aware of its uncommon manifestations. }\end{array}$ \\
\hline
\end{tabular}

Keywords: congenital nephrotic syndrome, congenital syphilis, nephrotic syndrome - early onset

\section{INTRODUCTION}

The prevalence of Congenital Syphilis (CS) has been increased worldwide in the last decade and became a public health concern [1]. World Health Organization (WHO) estimates that one million of pregnant women are infected annually, and Brazil is the second country in America in number of cases [2]. In 2018, there were 26,129 cases of congenital syphilis reported in Brazil, which was 5.2\% higher than the previous year [1].

Vertical transmission of syphilis can occur throughout pregnancy, and perinatal transmission is also possible, but early diagnosis and treatment eradicates disease in about $97 \%$ of cases [3].

Early manifestations of CS include hepatosplenomegaly, osteochondritis, pneumonitis, thrombocytopenia, intrauterine growth restriction, meningitis, cranial nerve palsies, hemorrhagic rhinitis, mucocutaneous lesions, skin desquamation or bullous lesions involving palms and soles [4]. Other manifestations like eye, kidney or heart involvement are rare, although they have been described elsewhere [4,5].

Congenital nephrotic syndrome (CNS) is also a rare condition, defined as proteinuria, hypoalbuminemia, hyperlipidemia and edema in the first 3 months of life [5]. Genetic defects are the major cause of CNS, however it might be also a part of a syndrome, or caused by maternal disease, congenital infection or alloimmunization $[5,6]$.

There are few reports documenting the association between infection and nephrotic syndrome [7-9]. Here we report a rare condition of a 2 month- old baby with CNS caused by CS.

\section{CASE REPORT}

A 68-day old female baby was referred to pediatric emergency care presenting with vomiting, lower limb edema, abdominal distension, oliguria and poor feeding. On further history, her mother was diagnosed with gestational syphilis, but she refused treatment. Physical examination revealed hepatosplenomegaly $(4.5 \mathrm{~cm}$ and $2 \mathrm{~cm})$, generalized edema, erythematous skin lesions and desquamation involving palms and soles.

Laboratory findings (Table 1) included anemia, thrombocytopenia, low serum albumin, proteinuria, hematuria, hyperlipidemia, C-reactive protein elevated, normal creatinine and urea. Infectious screenings (Hepatitis B and C, Toxoplasmosis, Rubella, Human Immunodeficiency Virus and Cytomegalovirus) were negative, except of Veneral Disease Research Laboratory test (VDRL) which was positive in both peripheral blood (at dilution 1:128) and cerebrospinal fluid (dilution 1:2). Long bone X- rays were normal.

The patient was treated with intravenous penicillin $\mathrm{G}$ for 10 days with clinical and laboratory improvement (Table 1). No specific measure for CNS treatment was taken and unrinalysis parameters normalized (Table 2). Follow- up after discharge confirmed CS with regression of non- treponemal titer (VDRL= 1:2) and treponemal test positive after one year of age (FTAABS IgG positive).

\section{DISCUSSION}

CS is a preventable disease, once the treatment of gestational syphilis can cure both mother and fetus. About two 
Table 1. Laboratory Tests Results before treatment (BT) and after treatment (AT) for Congenital Syphilis

\begin{tabular}{ccc}
\hline Laboratory results & BT & AT \\
\hline Hemoglobin $(\mathrm{g} / \mathrm{dL})$ & 7.0 & 9.6 \\
\hline Hematocrit $(\%)$ & 19.8 & 29.7 \\
\hline Leukocytes $\left(\mathrm{cels} / \mathrm{mm}^{3}\right)$ & 15,950 & 11,800 \\
\hline Platelets $\left(\mathrm{cels} / \mathrm{mm}^{3}\right)$ & 101,000 & 386,000 \\
\hline Urea $(\mathrm{mg} / \mathrm{dL})$ & 23.9 & 7.3 \\
\hline Creatinine $(\mathrm{mg} / \mathrm{dL})$ & 0.42 & 0.08 \\
\hline Albumin $(\mathrm{g} / \mathrm{dL})$ & 2.24 & 3.39 \\
\hline Total Colestherol $(\mathrm{mg} / \mathrm{dL})$ & 284.4 & 109 \\
\hline Triglycerides $(\mathrm{mg} / \mathrm{dL})$ & 319 & 63 \\
\hline C-reactive protein $(\mathrm{mg} / \mathrm{dL})$ & 20.3 & 0.5
\end{tabular}

BT: before treatment; AT: after treatment

Table 2. Urinalysis parameters before treatment (BT) and after treatment (AT) for Congenital Syphilis

\begin{tabular}{ccc}
\hline Urinalysis & BT & AT \\
\hline Ph & 6.0 & 5.5 \\
\hline Density & 1,015 & 1,015 \\
\hline Proteins & +++ & negative \\
\hline Hemoglobin & +++ & negative \\
\hline Red Cells & $650,000 / \mathrm{mL}$ & negative \\
\hline Leukocytes & $75,000 / \mathrm{mL}$ & negative \\
\hline 24 hours Proteinuria & $1,834.70 \mathrm{mg} / \mathrm{dL}$ & Not performed
\end{tabular}

BT: before treatment; AT: after treatment

thirds of untreated women transmit the disease to their child, who become symptomatic at the first 3 months of life $[2,4,10]$.

Early signs of CS are result of circulation of the Treponema pallidum through organs and tissues, triggering immune response, which causes vasculitis, necrosis and fibrosis. Immunocomplex deposition in the region of the glomerular basement membrane is related to renal disease, but the exact pathogenesis remains unknown [11-13]. Since the signs of CNS appear 6-8 weeks after birth, it seems that the immune response is most related to CNS than treponemal activity itself [14]. Renal involvement presents from mild albuminuria to severe disease, but the regression is fast after specific treatment, so CNS could be a transitory immunopathy in most cases [14].

Unfortunately, no biopsy was performed in this infant, but since Treponema pallidum circulates in all body, its presence in kidney cells does not confirm the correlation between CNS and CS [11,12]. The diagnosis of renal disease due to CS requires the evidence of clinical manifestations of CS in infant and/or positive serologic tests in the first weeks of life, evidence of maternal syphilis, signs of nephrotic syndrome and the absence of other causes and fast remission of symptoms after penicillin treatment $[13,15]$. This patient fullfills all these criteria.

Congenital infections are the second cause of CNS, but it should always be investigated as a cause first, because the treatment goal in these cases is to eradicate the pathogen, which per si is effective to reverse initial renal abnormalities $[13,14]$. The treatment with penicillin $G$ was enough to reverse the CNS in this infant, no other measure was necessary (restriction diet, steroids), which was an indicator that CS was implicated to CNS $[11,12,16,17]$.

CNS is a rare condition, and its association with CS is even lower $[12,15]$. Since the incidence of CS has been increasing, physicians should be attentive to this uncommon manifestation in order to provide early diagnosis and the correct treatment.

\section{CONCLUSION}

Congenital nephrotic syndrome is an uncommon complication of congenital syphilis. This case illustrates this association, and it should be an alert to health care providers be attentive to unusual manifestations of congenital syphilis.

Author contributions: All authors have sufficiently contributed to the study, and agreed with the results and conclusions.

Funding: No funding source is reported for this study.

Declaration of interest: No conflict of interest is declared by authors.

\section{REFERENCES}

1. Ministry of Health. Syphilis. Boletim Epidemiológico da Secretaria de Vigilância em Saude [Epidemiological Bulletin of the Health Surveillance Secretariat]. 1st ed. Brasilia: Ministry of Health, National Health Foundation. Boletim Epidemiológico-Epidemiological Bulletin 2019;V(1). Available at: http://www.aids.gov.br/pt-br/pub/ 2019/boletim-epidemiologico-sifilis-2019

2. Minas Gerais State Health Secretariat. Análise Epidemiológica de Sífilis - Panorama de 2017 [Epidemiological Analysis of Syphilis - Panorama 2017]. Vol. 3. Belo Horizonte: Minas Gerais State Health Secretariat; 2018. Available at: https://ammg.org.br/wp-content/ uploads/sifiis.pdf

3. Bezerra ML de MB, Fernandes FECV, de Oliveira Nunes JP, de Araújo Baltar SLSM, Randau KP. Congenital Syphilis as a Measure of Maternal and Child Healthcare, Brazil. Emerg Infect Dis.;25(8):1469-76. https://doi.org/10.3201/eid2508. 180298 PMid:31310223 PMCid:PMC6649332

4. Dobson, Tobias R Kollman SRM. Syphilis. In: Remington and Klein's infectious Diseases of the Fetus and Newborn Infant. 8 ed. Philadelphia, PA: Elsevier Saunders; 2016:51243.

5. Jalanko H. Congenital nephrotic syndrome. Pediatr Nephrol. 2020;24(11):2121-8. https://doi.org/10.1007/ s00467-007-0633-9 PMid:17968594 PMCid:PMC2753773

6. Joseph C, Gattineni J. Proteinuria and hematuria in the neonate: Current Opinion in Pediatrics. 2016 Apr;28(2):2028. https://doi.org/10.1097/MOP.0000000000000323 PMid: 26845146 PMCid:PMC4808592

7. Besbas N, Bayrakci US, Kale G, Cengiz AB, Akcoren Z, Akinci $D$, et al. Cytomegalovirus-related congenital nephrotic syndrome with diffuse mesangial sclerosis. Pediatr Nephrol. 2006;21(5):740-2. https://doi.org/10.1007/s00467006-0051-4 PMid:16523262

8. Poyrazoglu HM, Dursun I, Bastug F, Gunduz Z, Akyıldız BN, Tulpar S. Cytomegalovirus infection and haemophagocytosis in a patient with congenital nephrotic syndrome. Pediatr Nephrol. 2009;24(11):2257-9. https://doi.org/10.1007/s00467-009-1243-5 PMid:19603193

9. Hogan J, Fila M, Baudouin V, Peuchmaur M, Deschênes G, Niel $O$. Cytomegalovirus infection can mimic genetic nephrotic syndrome: a case report. BMC Nephrol. 2015;16(1):156. https://doi.org/10.1186/s12882-015-0152-z PMid:26395882 PMCid:PMC4580224 
10. Cooper JM, Sánchez PJ. Congenital syphilis. Seminars in Perinatology. 2018;42(3):176-84. https://doi.org/10.1053/ j.semperi.2018.02.005 PMid:29627075

11. Handoko ML, Duijvestein M, Scheepstra CG, de Fijter CWH. Syphilis: a reversible cause of nephrotic syndrome. BMJ Case Reports. 2013:1-3. https://doi.org/10.1136/bcr-2012008279 PMid:23396933 PMCid:PMC3604415

12. Kim YH, Song JH, Kim CJ, Yang EM. Congenital Syphilis Presenting with Only Nephrotic Syndrome: Reemergence of a Forgotten Disease. J Korean Med Sci. 2017;32(8):1374. https://doi.org/10.3346/jkms.2017.32.8.1374 PMid:28665076 PMCid:PMC5494339

13. Suskind R, Winkelstein JA, Spear GA. Nephrotic syndrome in congenital syphilis. Archives of Disease in Childhood. 1973;48(3):237-9. https://doi.org/10.1136/adc.48.3.237 PMid:4120917 PMCid:PMC1648095
14. Norero VC, Flores SM, Schilling IE, Gutiérrez LR. Compromiso Renal en la Lues Congénita [Renal Compromise in the Congenital Lues]. Rev chil pediatr. 1984;55(1):34-7. https://doi.org/10.4067/S0370-410619840 00100007

15. Aguayo TI, Martínez DG, Munzenmaycr BJ, Roscmberg GH, Fuente -Alba GJA. Síndrome Nefrótico Secundario a Lues Congénita. Rev chil pediatr. 1985;56(2):103-6. https://doi.org/10.4067/S0370-41061985000200009

16. Berbel O, Vera-Sempere F, Córdoba J. Síndrome nefrótico infantil por citomegalovirus. Nefrologia. 2003;23 (5):451-3.

17. Wang J-J, Mao J-H. The etiology of congenital nephrotic syndrome: current status and challenges. World J Pediatr. 2016;12(2):149-58. https://doi.org/10.1007/s12519-0160009-y PMid:26961288 